\title{
Research on Design of Analysis-based CRMSystem for Mobile Communications Industry and its Application
}

\author{
Zheng-qing Luo ${ }^{1}$, Shi-an Wang ${ }^{1}$, Xu-fang Chen ${ }^{2}$ \\ 1 School of Management, Hefei University of Technology, Anhui, \\ 230009,zqluojzz@mail.hf.ah.cn \\ 2 Mail Box 218, Hefei University of Technology, Anhui, 230009 \\ fangfang52065@sohu.com
}

\begin{abstract}
With the constant development of customer relationship management (CRM) theory and the maturity of business intelligence technology, the analysis-based CRM has become a hot topic in the academic field. Some enterprises have begun to put the analysis-based CRM to practice; however, there have been few successful applications because of the inadequate mastery of business intelligence technology and the insufficient understanding of business environment to apply the system. Through combining the characteristics of the mobile communications industry with those of mobile customer's consumption, this paper designs an analysis-based CRM system suitable for the mobile communications industry in China, which can provide useful references to the CRM of the mobile communications industry.
\end{abstract}

\section{Introduction}

We know that the domestic mobile communications industry has entered the steady development stage after its high speed development and that the market competition for the mobile communications industry has become more intense. The mobile communications industry is a typical industry needing huge fixed investment in its earlier stage, mainly including the construction of base-station and switch. The fixed expenditure in network and the equipment maintenance are relatively high, but the labor cost and other expenses are relatively small. The most remarkable characteristic of this industry is that the infrastructure investment has no direct relation with the quantity of its customer. That is to say, in a certain scope, there is no huge difference between having 10,000 customers and having only one customer

Please use the following format when citing this chapter:

Luo, Z., Wang, S., Chen, X., 2007, in IFIP International Federation for Information Processing, Volume 251, Integration and Innovation Orient to E-Society Volumel, Wang, W. (Eds), (Boston: Springer), pp. 652-662. 
in the infrastructure investment. In other words, the marginal cost of winning a customer is low. Therefore, the market competition of the mobile communications industry, in essence, is to compete for more customer resources. The core competence of mobile communications industry is to attract new customers, to retain the old customers and to implement effective CRM.

\section{Application and existing problems with the CRM system of the domestic mobile communications industry}

\subsection{Current application of CRM system for the mobile communications industry in China and existing problems}

At present, the domestic mobile communications industry has already established the mature service system, such as China Mobile's Business Operation Support System (BOSS), the former China Telecom's "97 projects" (like the networks administration system and the cost-calculating system) and China Unicom's synthetic account system. These systems have enabled the domestic mobile communications industry to operate automatically and they are similar to the analysis-based CRM system in certain aspects. However, each system does business in its own way and the data is dispersible among these systems. Therefore, it is difficult to integrate the customer's information, to say nothing of analyzing the data and mining valuable information. In this sense, the difficulty in the CRM implementation lies in how to establish a mature analysis-based CRM system by unifying the former operation system. In recent years, the overseas CRM suppliers have also developed the analysis-based CRM system in the mobile communications industry. There are few successful applications because the overseas suppliers have limited understanding of the commercial competition environment in China, and their models need perfecting.

\subsection{Existing problems in the practice of CRM}

(1) The incomplete and un-centralized customer information

The customer information that the mobile communications corporation has acquired is all dispersed in different departments. Usually, the market department acquires information through the name cards and the records of feedback table from the marketing campaign. In the sales department, the effective and dynamic information of important mobile customers is also fragmented and not comprehensive. The service sector only has the recorded information about customer's complaints and business applications.

(2) The more obvious limitation of customer value evaluation index

At present, the mobile communications corporation makes a rough judgment about customer value according to customer Average Revenue per User (ARPU). The ARPU value is unable to evaluate the customer value in the entire life cycle 
because it neglects the cost element and merely considers the customer current value instead of customer's latent value.

(3) The high percentage of customer loss and failure to analyze it comprehensively

At present, there is a high percentage of customer loss in the domestic mobile communications industry. According to the statistics of the China mobile, the customer loss in the four years spanning from 1999 to 2002 reaches as high as $11 \%$, $9.5 \%, 16.3 \%$ and $20.8 \%$ respectively. The loss trend is on the obvious rise [1]. Despite the fact that the operation businessmen know the customer loss, they fail to take effective measures to control and manage the drained customers. They don't know why they drain away and the structure of the drained customers.

\section{Structure of analysis-based CRM system and key technology}

\subsection{Structure of CRM system}

Typical analysis-based CRM system consists of the interaction level, the operation level and the analysis level, which will be further explained in this paper.

\subsection{Commercial intelligence, key technology of CRM system}

In 1989, Commercial intelligence initially proposed by Howard Dresner in Gartner Group which is a consultant firm in the US. Commercial intelligence assists the business decision through the application of support system [2]. The commercial intelligence is generally composed of the data warehouse, on-line analytical processing (OLAP), data mining and analysis tool. The data warehouse is the integrated, non-updated data group, used to support policy-making process [3]. Data warehouse should be integrated with the operational data. OLAP is mainly used to analyze data. The data mining technology, also called knowledge discovering, is mainly used to acquire useful information and knowledge from massive incomplete data. The analysis tool presents the analysis result for the end-users. Integration of these four parts can be used to make a comprehensive and in-depth analysis of enterprise's administration. 


\section{Design of analysis-based CRM system for the mobile communications industry}

\subsection{Structure of analysis-based CRM system}

According to the general structure of analysis-based CRM and mobile communications industry service pattern [4-6], the authors have designed an analysis-based CRM system for the mobile communications industry. This system mainly consists of the customer interaction level, the operation level and the analysis level, as is shown in figure 1.

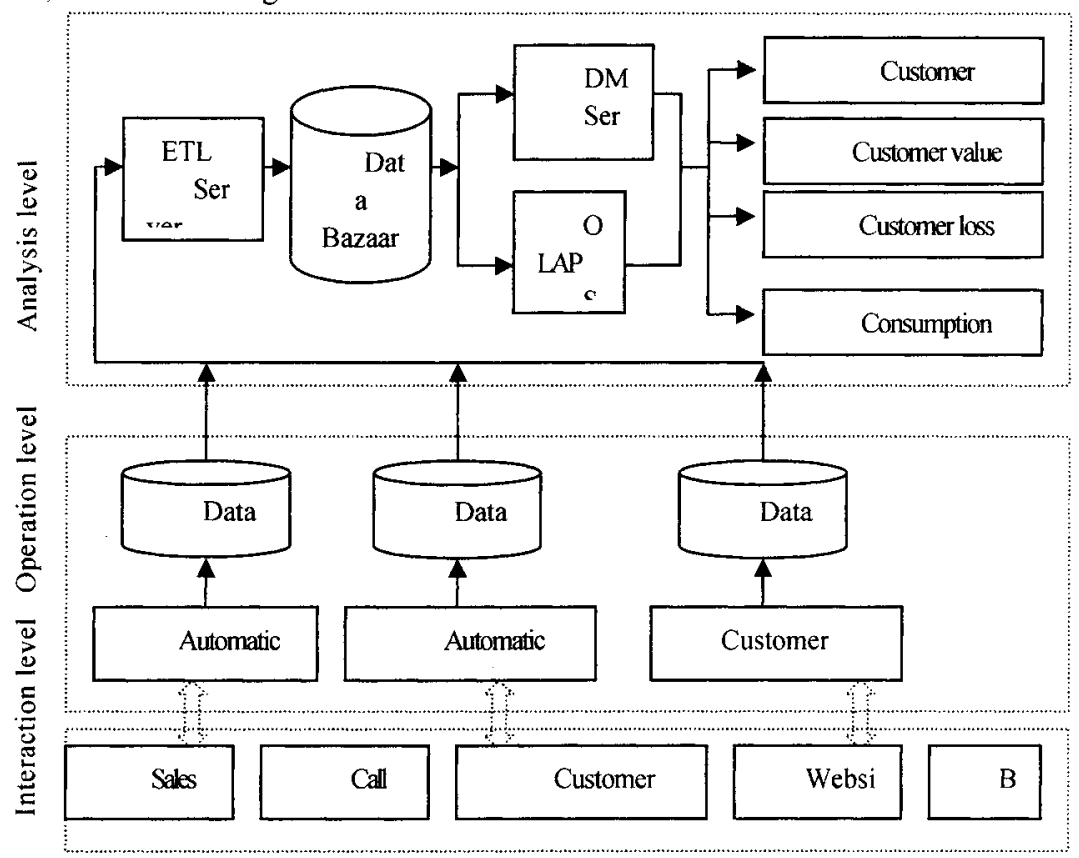

Figure 1 Analysis-based CRM system structure for mobile communications industry

\subsection{Main functions of analysis-based CRM system for the mobile communications industry}

\subsubsection{Customer interaction level}

The customer interaction level, the forepart of the analysis-based CRM system, is a direct contacting channel between the operation business and customers. The customer interaction level may achieve the following functions, as Table 1 shows. 
Table 1 Contact points and basic functions of customer interaction level

\begin{tabular}{|l|l|}
\hline $\begin{array}{l}\text { Contact } \\
\text { points }\end{array}$ & $\begin{array}{l}\text { Self-support service hall, Call center, Important client manager, Client delegate, } \\
\text { Agent service point, E-mail, Message, Website, Bill, Advertisement, etc. }\end{array}$ \\
\hline \multirow{3}{*}{$\begin{array}{l}\text { Basic } \\
\text { functions }\end{array}$} & $\begin{array}{l}\text { Providing customers with uniform products and services effectively } \\
\text { Responding to customer's personalized requests flexibly and quickly } \\
\text { Collecting customer's information } \\
\text { Finding out customer's demand } \\
\text { Retaining customers }\end{array}$ \\
\hline
\end{tabular}

\subsubsection{Management operation level}

The management operation level includes the automatic sale, automatic marketing and the customer service support system. Basic functions of the management operation level are indicated in table 2.

Table 2. Basic functions of management operation level

\begin{tabular}{|c|c|c|c|}
\hline $\begin{array}{c}\text { Operation } \\
\text { level }\end{array}$ & Automatic sale & $\begin{array}{l}\text { Automatic } \\
\text { marketing }\end{array}$ & $\begin{array}{l}\text { Customer Service } \\
\text { support }\end{array}$ \\
\hline $\begin{array}{l}\text { Basic } \\
\text { functions }\end{array}$ & $\begin{array}{l}\text { 1.selecting the number of } \\
\text { mobile phone and } \\
\text { handling e-order } \\
\text { 2.inputting, changing and } \\
\text { storing customer data } \\
\text { 3.managing history } \\
\text { of customer contact } \\
\text { 4.checking customer } \\
\text { credit } \\
\text { 5.recommending product } \\
\text { and service to } \\
\text { customer delegate }\end{array}$ & $\begin{array}{l}\text { 1.popularizing new } \\
\text { products and } \\
\text { training } \\
\text { 2.marketing } \\
\text { management } \\
\text { 3.interactive } \\
\text { marketing } \\
\text { 4.before and } \\
\text { aftersales } \\
\text { consultation } \\
\text { 5.changing } \\
\text { customer } \\
\text { information }\end{array}$ & $\begin{array}{l}\text { 1. dealing with } \\
\text { complaints } \\
\text { 2. controlling and } \\
\text { checking service } \\
\text { quality } \\
\text { 3. checking trouble in } \\
\text { website } \\
\text { 4.automatic phonic } \\
\text { response } \\
\text { 5.suggesting potential } \\
\text { sale opportunity }\end{array}$ \\
\hline
\end{tabular}

\subsubsection{Analysis level}

The analysis level, with complex structure and the use of commercial intelligence technology, is crucial to the entire analysis-based CRM system. As is demonstrated in Chart 1, the system structure and work flow of the analysis level is clearly explained. The analysis level, first, constructs many data warehouses of the marketing sector and the service sector by extracting, transforming and loading data from the automatic sale, automatic marketing and customer service systems databases. Then, analysts from the above sectors can visit the DM server and the OLAP server through the customer end program, the browser and the report system tool, so that the customer analysis function can be achieved. The analysis content includes: the segmentation of customers, the analysis of customer behavior, the analysis of customer value, the analysis of cross sales, the analysis of customer loss and the analysis of customer loyalties. 


\section{Research on customer value of analysis-based CRM system in the mobile communications industry}

This part researches on the analysis of the customer value because of the complex structure of the analysis-based CRM system and the limited pages .

\subsection{Design of customer value evaluation index system}

Based on the mobile communications customer value evaluation index system [7] designed by domestic scholar Qi Jia-yin in 2004, and resorting to China Mobile Business Analysis System Operation Criterion (the V1.0 version) [8] and China Unicom Business Analysis System Technology Criterion (the revised edition in 2004) [9], this paper has designed the following index system, as is shown in figure 2.

The system structure is divided into three levels. The first level mainly evaluates the customer value from the aspect of customer's current value and potential value. In the second level, income index and cost index can be used to evaluate the customer current value; the loyalty index and credit index can be used to show customer's latent value--the customer's stability and possibility of creating profits for the enterprise in the future. The third level is about the more concrete indexes.

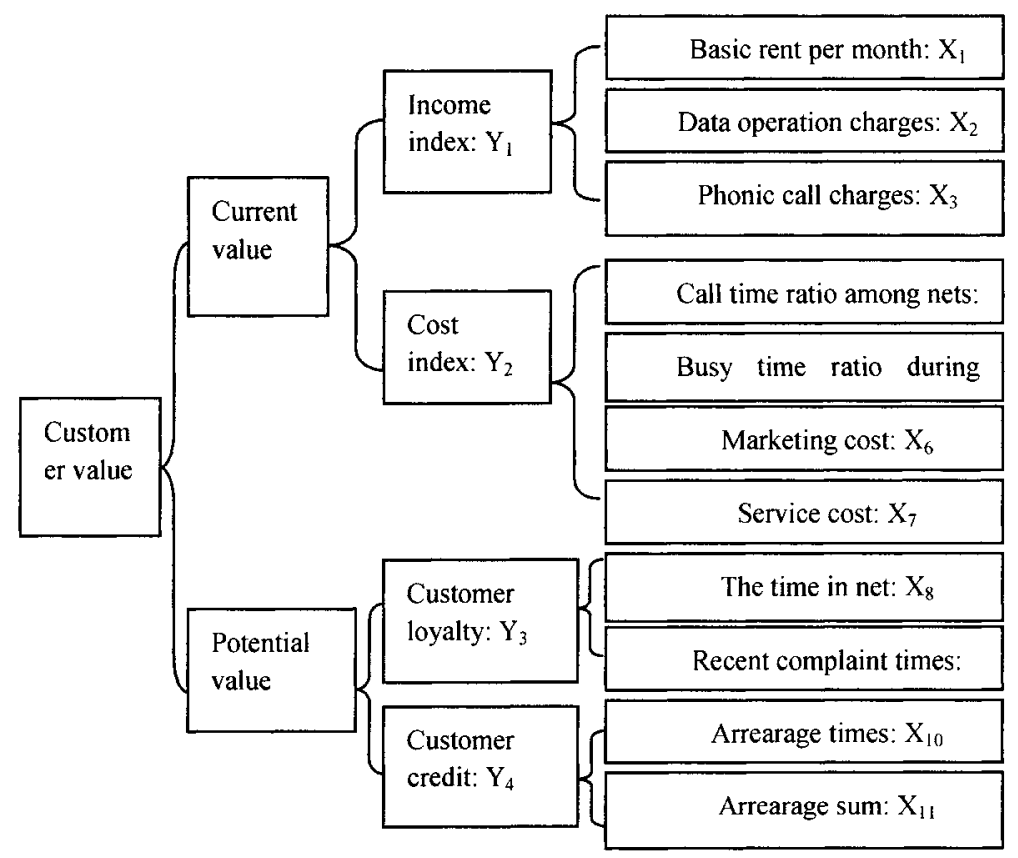

Figure 2 Evaluation index system of the mobile communications customer value 


\subsection{Computation model of Mobile customer value}

(1) Customer value formula

Firstly, pre-establish the value extent for every index in the evaluation system, and ascertain customer value in every index through the mapping method. Then, put different weights to different indexes. At last, obtain the customer value through adding all products from each index multiplying with its weight. The formula is expressed below:

$$
C V=\sum_{i=1}^{n} X_{i} \cdot R_{i}
$$

Where CV stands for the customer value, $\mathrm{Xi}$ denotes the value of index $\mathrm{i}$; $\mathrm{Ri}$ refers to the weight of index $\mathrm{i}$; $\mathrm{N}$ is the number of index.

(2) The method of ascertaining index weights in the formula

In this customer value model, the index system is divided into three hierarchies. Therefore, it is suitable to determine the index weights by resorting to the analytic hierarchy process (AHP). The three concrete steps are as follows. The first step is to construct the hierarchy model. This paper thinks of the customer value as the target level, the customer current value and the latent value as the criterion level, then each detailed index as the lower project level. The second step is to construct mutual comparative judgment matrix. We use the Delphi method to evaluate the importance of every index according to 1-9 scale by inviting several marketing experts in the field of the mobile communications industry, and then construct reasonable mutual comparative judgment matrix to satisfy the following condition.

$$
A=\left(R_{1}\right)_{m \times n}
$$

Where $R \mathrm{ij}>0, \mathrm{Rij}=1 / \mathrm{Rji}$, $\mathrm{Rii}=1$, also $\mathrm{i}, \mathrm{j}=(1,2 \ldots \ldots, \mathrm{n})$, and $\mathrm{Rij}$ is the relative importance ratio between index $i$ and index $j$. The third step is to calculate the index weight in each level according to the judgment matrix. The concrete computation process can be found in literature [10].

(3) Issues which need paying attention to in the determining of index weight

Weight of various indexes in this index system should be dependent on the actual situation. Because there are some differences in the achievement goal of different mobile communications companies in different areas. The level of customer consumption and the expert's preference are different too. For example, the company which attaches importance to the cash flows can increase the weight of the monthly expenditure index, while the company under heavier arrearage pressure should increase customer credit weight correspondingly.

\section{Empirical analysis of customer value in a certain mobile communications company}

We investigated one of China Unicom companies in Anhui province during our research. This company is mainly engaged in comprehensive telecommunications service, such as GSM130, CDMA133 mobile phone, 193, the IP long-distance telephone, 165-net and so on. At present, the company possesses 12 business halls by 
itself, 89 associated business halls, 344 charge points, 1,400-kilometer cable, and the capacity of mobile exchanges for 485,000 . The number of staff in the company is 345 and it has two subsidiaries.

\subsection{Basic status of customers in this company}

We referred to the basic information about GSM users and the CDMA users from the company's costs system and the account system in March, 2005. Through data handling, we obtained the value of user's ARPU and the distribution of total call charges, as is shown in table 4. Besides, we extracted call charges details of 1,000 customers from March to May in 2006 at random. Among them, details of a certain customer whose mobile phone number is $1308300^{* * * *}$ are shown in table 3.

Table 3 A certain customer's detailed call charges list

\begin{tabular}{|l|l|l|l|l|l|l|l|l|l|}
\hline Index & $\begin{array}{l}\text { Basic } \\
\text { rent per } \\
\text { month }\end{array}$ & $\begin{array}{l}\text { Call } \\
\text { charges }\end{array}$ & $\begin{array}{l}\text { Value } \\
\text { added } \\
\text { charges }\end{array}$ & $\begin{array}{l}\text { Arrear- } \\
\text { age in } \\
\text { the past }\end{array}$ & $\begin{array}{l}\text { Advance } \\
\text { payment }\end{array}$ & $\begin{array}{l}\text { Overd- } \\
\text { ue fees }\end{array}$ & $\begin{array}{l}\text { Total call } \\
\text { time } \\
\text { (minutes) }\end{array}$ & $\begin{array}{l}\text { Call time } \\
\text { among nets } \\
\text { (minutes) }\end{array}$ & $\begin{array}{l}\text { Busy } \\
\text { time call } \\
\text { (minutes) }\end{array}$ \\
\hline $03 / 05$ & $¥ 20.0$ & $¥ 53.9$ & $¥ 12.23$ & $¥ 0.00$ & $¥ 50.00$ & $¥ 0.00$ & 303.24 & 162.56 & 82.45 \\
\hline $04 / 05$ & $¥ 20.0$ & $¥ 65.5$ & $¥ 9.45$ & $¥ 0.00$ & $¥ 80.00$ & $¥ 0.00$ & 383.54 & 87.25 & 92.34 \\
\hline $05 / 05$ & $¥ 20.0$ & $¥ 52.8$ & $¥ 13.46$ & $¥ 0.00$ & $¥ 50.00$ & $¥ 0.00$ & 252.65 & 125.76 & 102.32 \\
\hline
\end{tabular}

Table 4 GSM and CDMA customer's ARPU distribution

\begin{tabular}{|l|l|l|l|l|l|l|l|}
\hline $\begin{array}{c}\text { ARPU } \\
\text { (Yuan) }\end{array}$ & $\begin{array}{c}\text { Custo- } \\
\text { mer } \\
\text { amount }\end{array}$ & Ratio & $\begin{array}{c}\text { Cumu- } \\
\text { lative } \\
\text { ratio }\end{array}$ & $\begin{array}{c}\text { Call } \\
\text { charges }\end{array}$ & Ratio & $\begin{array}{c}\text { Cumul- } \\
\text { Ative } \\
\text { ratio }\end{array}$ & $\begin{array}{c}\text { Aver- } \\
\text { age } \\
\text { ARPU }\end{array}$ \\
\hline $0-30$ & 32653 & 0.094997 & 1.0000 & 869875.92 & 0.029150 & 1.00000 & 26.64 \\
\hline $30-50$ & 94273 & 0.274269 & 0.9050 & 4098808.91 & 0.137356 & 0.96703 & 43.48 \\
\hline $50-100$ & 162937 & 0.474033 & 0.6307 & 11641848.6 & 0.390134 & 0.82968 & 71.45 \\
\hline $100-200$ & 35556 & 0.103443 & 0.1567 & 6194566.32 & 0.207588 & 0.43954 & 174.22 \\
\hline $200-300$ & 9552 & 0.027790 & 0.0532 & 2414287.93 & 0.080906 & 0.23195 & 252.75 \\
\hline $300-500$ & 6702 & 0.019498 & 0.0254 & 2877436.68 & 0.096426 & 0.15105 & 429.34 \\
\hline $500-800$ & 1588 & 0.004620 & 0.0059 & 1145472.04 & 0.038386 & 0.05462 & 721.33 \\
\hline $\begin{array}{l}800- \\
1000\end{array}$ & 331 & 0.000963 & 0.0013 & 315552.23 & 0.0105746 & 0.01623 & 953.33 \\
\hline$>1000$ & 133 & 0.000387 & 0.0003 & 282758.21 & 0.009475 & 0.00566 & 2126.0 \\
\hline
\end{tabular}

According to table 4, we conclude that the customer data of this China Unicom company are approximately subject to the normal distribution through the statistical analysis and computation. We can obtain $\mathrm{ARPU}=86.81$. Among them, $43.95 \%$ call charges is paid by $15.67 \%$ customers. The computation model is as follows.

\subsection{Empirical analysis of customer value computation model}

(1) Giving piecewise value to each index in the evaluation system 
We first pre-establish the value extent for index $X_{1}$ to index $X_{11}$, and give corresponding value $(20,40,60,80,100)$ to each different value extent by using centesimal mode. Considering there is little difference between each mobile customer's marketing cost index and service cost index and because it's difficult to obtain data of this subsidiary's marketing cost and service cost, indexes $X_{6}$ and $X_{7}$ are omitted. Piecewise value of other indexes is shown in table 5 .

Table 5 Piecewise value of index

\begin{tabular}{|l|l|l|l|l|l|}
\hline Index value & 20 & 40 & 60 & 80 & 100 \\
\hline $\mathrm{X}_{1}:$ Basic rent per month & 10 & 15 & 20 & 30 & 50 \\
\hline $\begin{array}{l}\mathrm{X}_{2}: \text { Data value-added operation } \\
\text { charges }\end{array}$ & $0-50$ & $50-200$ & $200-500$ & $500-800$ & $\geqslant 800$ \\
\hline $\mathrm{X}_{3}:$ Call charges & $0-50$ & $50-200$ & $200-500$ & $500-800$ & $\geqslant 800$ \\
\hline $\mathrm{X}_{4}:$ Call time ratio among nets & $1-0.8$ & $0.8-0.6$ & $0.6-0.4$ & $0.4-0.2$ & $0.2-0$ \\
\hline $\mathrm{X}_{5}:$ Busy time ratio during call & $1-0.8$ & $0.8-0.6$ & $0.6-0.4$ & $0.4-0.2$ & $0.2-0$ \\
\hline $\mathrm{X}_{8}$ :The time in net(year) & $0-1$ & $1-2$ & $2-3$ & $3-4$ & $>4$ \\
\hline $\mathrm{X}_{9}:$ Recent times of complaint & $>3$ & 3 & 2 & 1 & 0 \\
\hline $\mathrm{X}_{10}:$ Times of arrearage & $>8$ & 8 & 4 & 2 & 0 \\
\hline $\mathrm{X}_{11}:$ Sum of arrearage & $>200$ & $200-100$ & $100-50$ & $50-20$ & $20-0$ \\
\hline
\end{tabular}

We can obtain corresponding index value $X_{1}=60, X_{2}=20, X_{3}=40, X_{4}=80, X_{5}$ $=80, X_{8}=40, X_{9}=100, X_{10}=100, X_{11}=100$ through computation by taking the customer whose mobile number is $1308300^{* * * *}$ shown in table 4 for example.

(2) Selecting each index's weight

In order to clarify the importance of every correlated factor in the index system, we communicated sufficiently with related staff in the market administration department during our investigation. For the sake of computing simplicity, we apply the AHP method to ascertain weight for the income index level. For other levels, we use the direct evaluation method to ascertain weight. The judgment matrix of income index level is as follows:

$$
Y_{1}=\left[\begin{array}{ccc}
1 & 1 / 5 & 1 / 3 \\
5 & 1 & 3 \\
3 & 1 / 3 & 1
\end{array}\right]
$$

Where $W=(0.105,0.637,0.258)^{\prime}, \lambda \max =3.038, \mathrm{CI}=0.019, \mathrm{RI}=0.58, \mathrm{CR}=0.033$

According to the customer value computation model, we can obtain:

$\mathrm{CV}=0.6\left(0.8 \mathrm{Y}_{1}+0.2 \mathrm{Y}_{2}\right)+0.4\left(0.5 \mathrm{Y}_{3}+0.5 \mathrm{Y}_{4}\right)$

Where $_{1}=0.105 \mathrm{X}_{1}+0.637 \mathrm{X}_{2}+0.258 \mathrm{X}_{3}$

$\mathrm{Y}_{2}=0.6 \mathrm{X}_{4}+0.4 \mathrm{X}_{5}, \mathrm{Y}_{3}=0.3 \mathrm{X}_{8}+0.7 \mathrm{X}_{9}, \mathrm{Y}_{4}=0.5 \mathrm{X}_{10}+0.5 \mathrm{X}_{11}$

(3) Calculating customer's customer value (CV) in the sample

Substituting the customer data shown in Table 3 into the former CV formula, we can obtain customer value $C V=98.1$ of No. $1308300^{* * * *}$, and other customers' CV can be computed by using the same principle. 
In order to calculate the sample customer $\mathrm{CV}$, we have established a programming using FOXPRO. Substitute the sample data into the programming to obtain the distribution of the 1,000 customers' CV. The statistics indicates the sample customer's CV is approximately subject to the normal distribution. Thus, we tested the reasonableness of this customer value computation model.

From the statistics, we may find two kinds of customers. One kind of customer's $\mathrm{CV}$ is high, but their ARPU value is low. This explains that this kind of customer's monthly consumption is low, but maybe their call time ratio among nets is smaller, the time they attend the net is longer, and their loyalty is higher. Therefore, it is unreasonable to evaluate this kind of customer by using the ARPU value merely. The other kind of customer's CV is lower, but their ARPU value is higher. This shows that this kind of customer's monthly consumption is high. However, their call ratio between nets is high, arrearage frequently occurs, their credit is low, and they are easy to drain away. For this kind of customers, if their customer value is evaluated by merely using the ARPU value, it is likely that the virtual height of the ARPU value will occur, which does harm to the marketing decision. Therefore, adequate importance should be attached to these two situations.

\section{Conclusion:}

This paper mainly analyzes problems existing in the CRM practice of domestic mobile communications industry. In order to solve these problems, we design the analysis-based CRM system for the mobile communications industry. The system structure has three levels, including the customer interaction level, the operation level and the analysis level. The functions for each part are designed and expatiated amply in the paper. According to the characteristics of domestic mobile communications industry and the characteristics of customer's consumption, we focus our research on the customer value. Moreover, we design a reasonable and comprehensive customer value evaluation index system. And we innovatively construct new model for the customer value computation. Finally, the paper tests the practicability and rationality of the analysis-based CRM system and the customer value computation model by giving an example. In a word, the paper has two scientific contributions. One is designing the structure and function of analysis-based CRM system for the mobile communications industry. The other is constructing a more scientific and new model for the customer value computation.

\section{References:}

1. D. Qi Jia-yin, Empirical research on customer entire life cycle management and mobile operation industry, Beijing University of Posts and Telecommunications, 2004

2. D. Peng Ying, Constructing analysis-based CRM by using commercial intelligence, University of International Business and Economics, 2003 
3. M Inmon, W.H.Building, Data Warehouse, QED Technical Publishing Group, 1999:12-13

4. Tromp, S.; Versendaal, J.; Batenburg, R.; Van Duinkerken, W.; Business/ITAlignment for Customer Relationship Management in the Telecommunication Industry: Framework and Case Study, Information and Communication Technologies, 2006. ICTTA '06. 2nd. Volume 1, 24-28 April 2006 Page(s):262 - 267

5. Camponovo, G.; Pigneur, Y.; Rangone, A.; Renga, F.; Mobile customer relationship management: an explorative investigation of the Italian consumer market, Mobile Business, 2005. ICMB 2005, International Conference on 11-13 July 2005 Page(s): $42-48$

6. Anderson, W.O., Jr, Customer relationship management in an e-business environment, Change Management and the New Industrial Revolution, 2001, IEMC '01 Proceedings, 7-9 Oct. 2001 Page(s):311 - 316

7. J. Qi Jia-yin, Designing customer value evaluation index system for mobile communications industry, Chinese science and technology paper on-line, 2004, 5 8. China Mobile Business Analysis System Operation Criterion, V1.0 version, China mobile communications company

9. China Unicom Business Analysis System Technology Criterion, in 2004, revised edition, The department of cost calculating, settlement, and information system from China Unicom Business headquarters

10. M. Du Dong, Pang Qing-hua, Selection of modern comprehensive evaluation method and cases, Qinghua University Press, 2005 